\title{
COVID-19: A positive prospect of pandemic situation
}

\author{
Vinod Kumar ${ }^{1 *}$, Chandra Mohan ${ }^{2}$, Dolly Rani $^{3}$, Savita Pandey ${ }^{4}$ and Vikas Saini ${ }^{5}$ \\ ${ }^{1}$ Asst. Prof., SMAS, K. R. Mangalam University, Gurugram 122103, Haryana, India. \\ ${ }^{2}$ Asst. Prof., SBAS, K. R. Mangalam University, Gurugram 122103, Haryana, India. \\ ${ }^{3}$ Amity University, Noida Utter Pradesh 201313, India \\ ${ }^{4,5}$ K. R. Mangalam University, Gurugram 122103, Haryana, India \\ *vinod.kumar@krmangalam.edu.in
}

\begin{abstract}
:
In 2019, human race again came across a highly transmittable and pathogenic viral infection viz. COVID-19 and along with its pandemic nature, caused severe acute respiratory syndrome (SARS), and owes its emergence from the local seafood market of Wuhan city, China. Corona virus is currently prevalent all over the world wherein it caused infection in more than $1,30,000$ individuals worldwide with mortality rate nearby $3 \%$ in approximately 120 countries within a short span of time and the infection due to this virus is still on a higher verge. Apart from this as per WHO report on air pollution revealed around 2.4 and 2.2 million deaths in South East Asian and Western Pacific regions respectively. Both conditions are deadly in their respective prospects, although lockdown, preventive measure which avoid spreading of COVID-19 infection, indirectly lead to significant drop down in air pollution globally. However, this effect is not permanent and it is for being a time but it develops a hope that together we can fight against both.
\end{abstract}

Keywords:

COVID-19; Wuhan; Pandemic; Air Pollution; Nitric Oxide; PM2.5.

Article Received: 18 October 2020, Revised: 3 November 2020, Accepted: 24 December 2020

\section{Introduction}

Today in all over the world, one name is to resound, COVID-19, which caused by novel corona virus SARSCoV-2 or 2019- $\mathrm{nCoV}$, originating in Wuhan, China [1], infected more than 50,0 823,62,600 people and around 40,598 deaths in more than 120 countries, globally. On $30^{\text {th }}$ January 2020, World Health Organisation (WHO) has declared public health emergency of international concern. According to WHO reports of 01 April, 2020 stated that in Western Pacific Region 106,422 confirmed cases (1,554 new) 3,701 deaths (30 new), European Region 464,212 confirmed cases $(40,266) 30,089$ deaths $(3,395$ new), South-East Asia Region 5,175 confirmed cases (960 new) 195 deaths (29 new), Eastern Mediterranean [2] Region 54,281 confirmed cases (3,932 new) 3,115 deaths (161 new), Region of the Americas 188,751 confirmed cases (25,737 new) 3,400 deaths (564 new) and African Region 4,073 confirmed cases (287 new) 91 deaths (14 new). However, in India, according to the Ministry of Health \& Family Welfare (MoHFW) total 5734, COVID-19 confirmed cases, and 166 deaths have been reported in 29 states/union territories till $9^{\text {th }}$ April 2020 [3].

Currently, our focus is only on how to stop the spreading of COVID-19 infection and we forget another problem named pollution which is equally deadly as COVID-19. As per WHO reports air pollution and UV rays affects all in the world, however its impact is around $97 \%$ in low/middle income countries and $49 \%$ in high income countries $[4,5]$ which caused deaths of around 7 million people every year globally due to the fine particles like PM 2.5 and various harmful gases like $\mathrm{NO}_{2}$, that lead to heart disease, lung cancer, chronic obstructive pulmonary and respiratory infections etc. apart from this pollution also showing its harmful effect on plants which leads to alteration in phytoconstituents and other therapeutic activities [6]. However, this data becomes more destructive in regions wise; Almost 2.4 and 2.2 million deaths were reported in South East Asian and Western Pacific regions respectively, Africa bears 980,000 deaths, around 
475,000 deaths in Eastern Mediterranean region, 348,000 deaths in Europe and 233,000 deaths in Americas were reported in a year. Now, on the basis of above data we can say that pollution is much deadly as compare to COVID-19.

\section{Impact of COVID-19 on Air quality}

Novel coronavirus infection creaks the health care system worldwide but it temporarily also clears the environment. However, a study has been carried out by the researchers of Harvard T.H. Chan School of Public Health in 3,080 counties, comparing the fine particulate matter level (PM 2.5)/ air pollution with coronavirus death and stated that the people living in high population areas are on high risk of death/died as compared to who's live in less polluted areas [7]. Although this deadly situation caused a stir in the whole world, but we know that "Every cloud has a silver lining". This has been proved by the data released by NASA's pollution monitoring satellites and

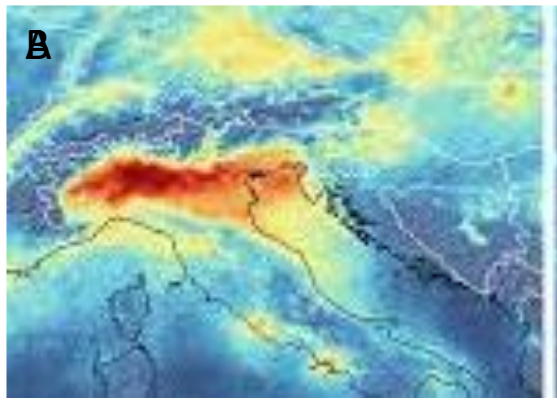

Fig. 1. Italy Nitrogen Dioxide level from A) 01 January 2020 B) 11 March 2020

According to a survey conducted by the Central Pollution Control Board (CPCB), Delhi, India remarkable improvement has been observed on 06 April, 2020, in the Delhi and NCR regions with $35-40 \%$ drop down in PM-10 and PM-2.5 levels in 21 days lockdown [10], which is satisfactory level as per System of Air Quality and Weather

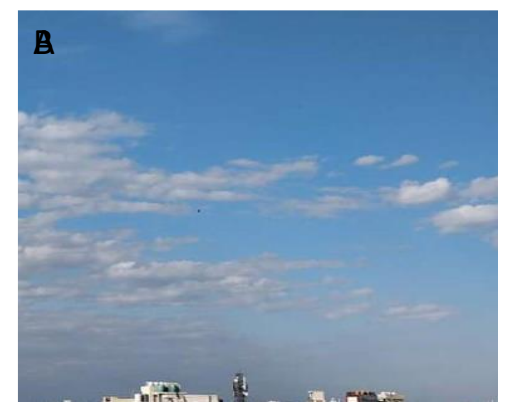

Fig. 2. A) Showed Clean Sky of Delhi- NCR various scientific reports, detected significant decreases air pollution (nitrogen dioxide level, $\mathrm{CO}_{2}$ levels, Water pollution and PM 2.5 level) around the world.

Marshall Burke, environmental economist of Stanford University, California, observed drop of air pollution in various parts of China and stated that dropdown in pollution saved more lives exceed COVID-19 deaths in China. Based on the collected [8] data Burke also says that lives of 4,000 children age less than 5 years and 73,000 adults over 70 year age in China saved by two months of pollution reduction.

The satellite data obtained from Tropomi instrument on the Copernicus Sentinel-5P satellite [9] over northern Italy from 01 January to 11 March 2020, showed large drop in air pollution (specifically nitrogen dioxide) due to complete lockdown shown in Fig. 1

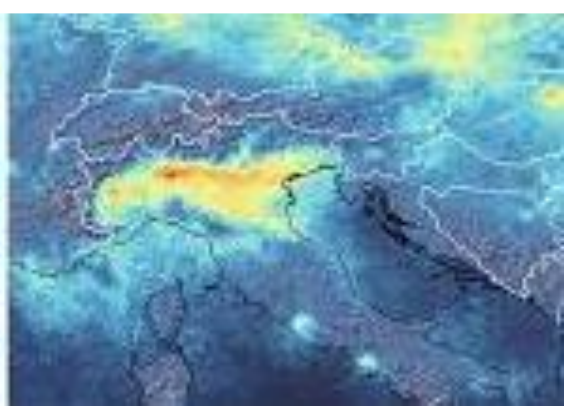

Forecasting and Research (SAFAR) shown in Fig. 2.

Apart from this, residents of Jalandhar, Punjab statesof India could saw the unexpected view of Dhauladhar mountain range, Himachal Pradesh, India by naked eyes on Friday [11], after one week lockdown imposed on the March 24, 2020 midnight in India shown in Fig. 2.

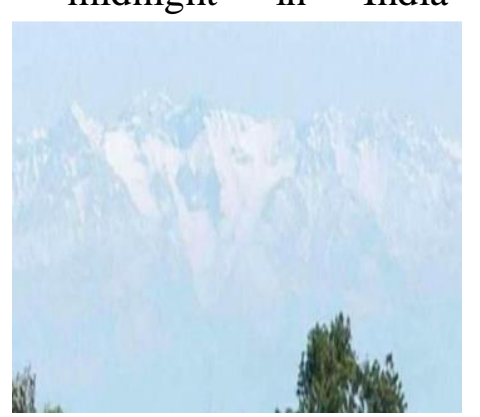

B) Naked eye view of HP Mountains 


\section{Discussion and Conclusion}

Currently, almost every country has taken precaution to avoid spreading the COVID-19 and lockdown is the best weapon till date available to fight against this deadly viral infection. Although COVID-19 is dangerous to humans, its sacred method called lockdown helps in the rebirth of nature. However, such effects are for the time being but raise the question, can we together make it permanent. COVID-19 an epidemic condition provides us an opportunity to think about our motherland and nature. Now it's depends upon us weather we take it as a fortuity to rebirth our nature or just skip it, as we did always.

\section{Funding}

None.

\section{Conflict of Interest}

The authors have no conflict of interest.

\section{Acknowledgment}

None.

\section{References}

[1] Shereen MA, Khan S, Kazmi A, Bashir N, Siddique R. COVID-19 infection: Origin, transmission, and characteristics of human Coronaviruses. J Adv Res 2020; 24 : 91-8.

[2] Organization WHO. Laboratory testing for coronavirus disease 2019 (COVID-19) in suspected human cases: interim guidance, 2 March 2020. World Health Organization; 2020.

[3] Information Network for Epidemics (EPIWIN) dashboard. https://www.who.int/docs/defaultsource/coronaviruse/situationreports/20200330-sitrep-70-covid19.pdf?sfvrsn=7e0fe3f8_2.

[4] Katherine E, Sleeman KE, Brito MD, Etkind $\mathrm{S}$, Nkhoma K, Guo P, et al. The escalating global burden of serious health-related suffering: projections to 2060 by world regions, age groups, and health conditions. Lancet Glob Health 2019; 7 : 883-92.

[5] Kumar V, Pal M, and Dhiman, N. Determination of sun protection factor in different extract of Eulaliopsis binata, Plant Archives, 2019; 19(2), 185-187

[6] Kumar V, Sharma AK, Rajput SK, Pal M, Dhiman N. Evaluation of phytochemical, toxicological and pharmacological profile of Eulaliopsis binata leaf extracts. Toxicol Res. 2018; 7: 454-464

[7] https://www.hsph.harvard.edu/news/hsph-inthe-news/air-pollution-linked-with-highercovid-19-death-rates/.

[8] https://www.sciencealert.com/here-s-whatcovid-19-is-doing-to-our-pollution-levels.

[9] Conticini E, Frediani B, Caro D. Can atmospheric pollution be considered a cofactor in extremely high level of SARSCoV-2 lethality in Northern Italy? Environ Pollut 2020; 114465. https://doi.org/10.1016/j.envpol.2020.11446 5

[10] https://economictimes.indiatimes.com/news/ politics-and-nation/covid-19-impact-delhibreathes-third-week-of-cleanair/articleshow/75001969.cms?utm_source= contentofinterest\&utm_medium=text\&utm campaign $=\mathrm{cppst}$

[11] https://timesofindia.indiatimes.com/travel/de stinations/covid-19-impact-people-injalandhar-shocked-to-see-views-ofdhauladhar-range-for-the-firsttime/as74970585.cm 